(C) Journal «Agrarian History», № 1, 2020.

Publication date: February, 15, 2020

\title{
THE USE OF THE ADAYEV HORSE IN AGRICULTURE OF KAZAKHSTAN
}

\author{
Vitaly Dorokhin ${ }^{1}$ \\ ${ }^{1}$ Voronezh State Technical University, Voronezh, Russia, \\ E-mail: s1te@bk.ru
}

\begin{abstract}
The article examines the Adaevskaya horse (now more than 34 thousand heads), bred in Kazakhstan on the vast territory of the Aralokaspian desert. It became widespread in the current administrative boundaries of the Mangistau and Atyrau regions, occupying more than 30 million hectares of pastures.

The Adayev horse comes from the Adayev tribe of Kazakhs who roamed the Aral-Caspian lowland. In the harsh conditions of the Mangistau Peninsula and the Ustyurt desert plateau, it cannot be replaced by any other animal. In this regard, the problem of the development of productive horse breeding in the region, its rational use had not only significant economic, but also social significance, since more than $90 \%$ of food products were imported from outside. In addition, there was an acute shortage of kumis and horse meat.

Typological research has been carried out in Kazakhstan for a long time. As a rule, the object of research was the Kazakh horse with its numerous species and offspring. At the beginning of the last century, breeders faced completely different tasks - the production of a working and army horse. Here, the main attention was paid to the crossing of local mares, well adapted to herd keeping, with stallions of factory breeds - purebred, Don, heavy draft, as well as Arab and Akhal-Teke.
\end{abstract}

Keywords: horse, earth, man, nature, food.

\section{INTRODUCTION}

At the end of the 1970s, the threat of extinction of this most valuable ecotype of the Kazakh breed loomed, and the problem arose of keeping it clean. On the other hand, the problem was exacerbated by the lack of science-based industry technology for meat and dairy herd horse breeding in Kazakhstan to date. It was necessary to develop scientifically grounded methods of using natural pastures with the simultaneous application in practice of methods to improve breeding qualities, which would allow answering a number of theoretical and practical questions, which would contribute to an increase in the production of milk and meat, which is a much needed product in this region. The ethology of the Adai horses has not been studied at all. began.

At the end of the 1980s, systematic research and selection and breeding work with the Adayev horse 


\section{RESEARCH METHODS AND RESULTS}

In addition to experimental materials, the article uses all the main domestic and foreign scientific sources available to us. The materials of scientists (Yu.N. Barmintsev, B.Kh. Sadykov, I.N. Nechaev, A. Imangaliev, N.V. Anashina, S.S. Rzabaev, N.A. Kikebaev, etc.) systematically studied the populations of Kazakh horses in Kazakhstan.

Of great relevance was the study of economically useful traits, the formation of breeding lines, families and the development of methods to improve the productive qualities of horses of the Adayev ecotype, using cheap pasture feed. The importance of their solution determines the relevance of the research.

The data obtained make it possible to formulate scientifically based conclusions and practical recommendations for improving horse meat production technology, as well as developing technological parameters for the production of pedigree products. The effective methods of improving the breeding and productive qualities of horses of the Adayev ecotype have been revealed, and a progressive technology for the production of horse breeding products in the conditions of the Aralo-Caspian desert zone has been proposed.

The results of purebred breeding of Adai horses had a positive effect on improving the physique and increasing the live weight of horses. The increase in the live weight of the offspring already in the first generation reached $24 \mathrm{~kg}$, and the genetic progress in live weight in the III-IV generation, in comparison with the initial herd, reaches 55.9-61.0 kg. High growth vigor was noted in horses feeding in the Mangystau desert. Animals at the age of 30 months reached an average live weight of $318.5 \mathrm{~kg}$, the slaughter yield was $53.4 \%$.

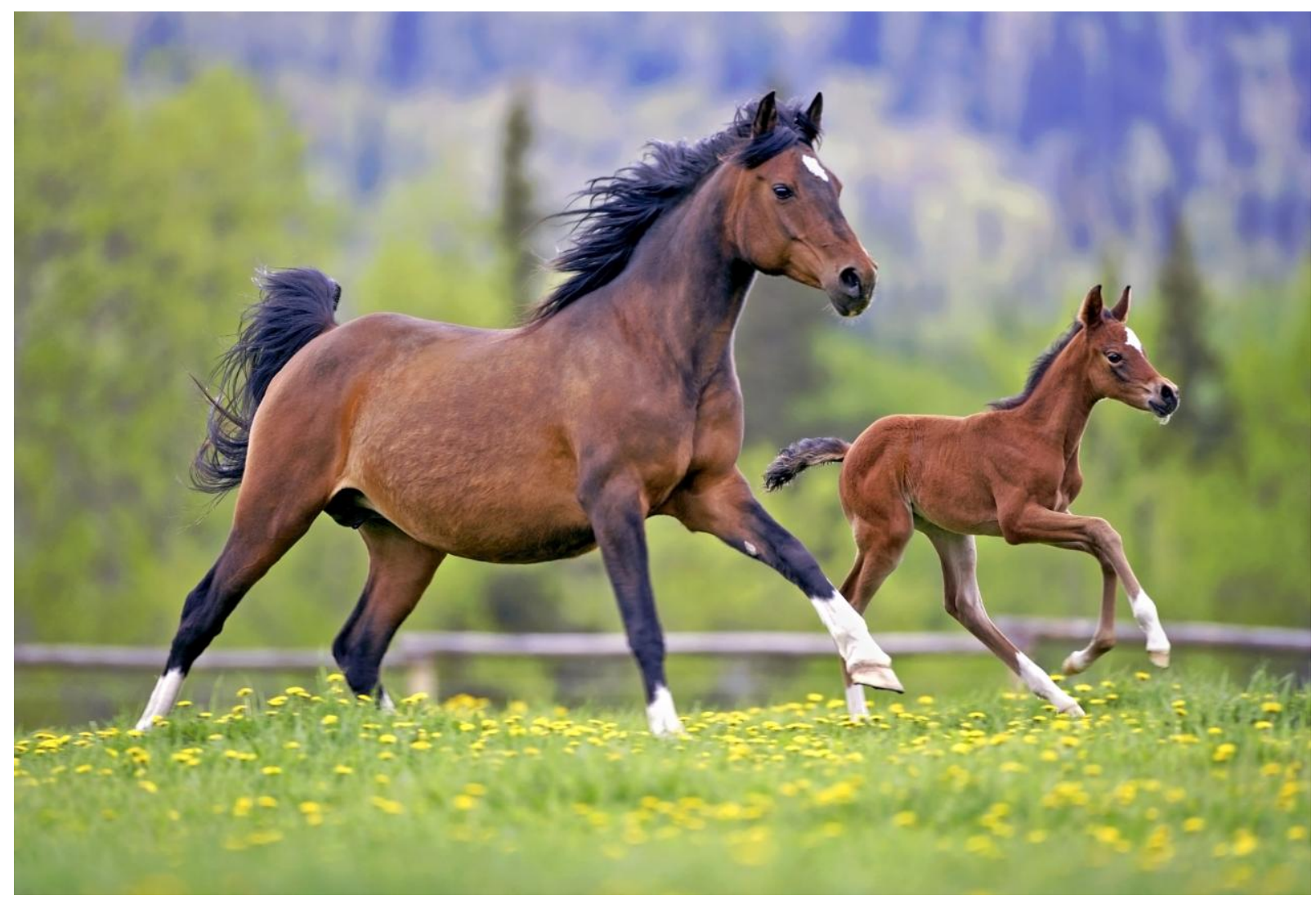


Further prospects for the development of meat and dairy herd horse breeding in the republic are determined by the fodder capacity of pastures (180 million hectares), which makes it possible to increase the number of herd horses in the country by 2030 to 3.0 million heads, which will provide more than 300 thousand tons of high-quality horse meat per year.

Setting up experiments to establish a genetically determined level of productivity of modern Adaev horses in the breeding area, studying the hidden reserves of increasing productivity and, on this basis, developing a scientific and practical substantiation of methods for improving this population is one of the most pressing problems of horse breeding in the region. The zootechnical characteristics of the emerging breeding lines of outstanding ancestors and mother families make it possible to assess the productive qualities of modern Adayev horses.

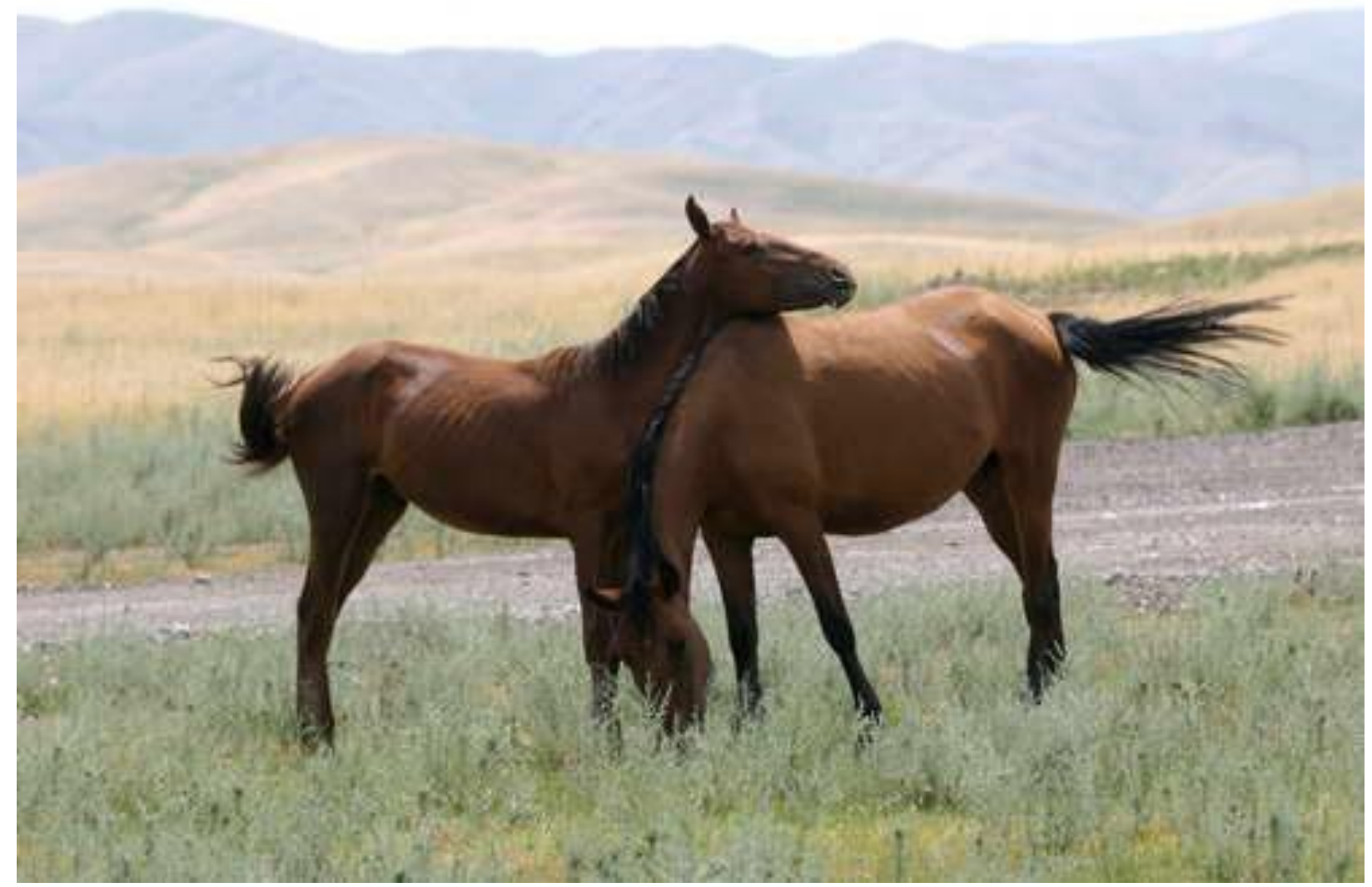

As a result of long-term selection and breeding work in the gene pool farms of the Aralokaspian desert, a highly productive herd of Adaev horses was created with a total livestock of more than 3000 heads. 3 breeding lines and 4 brood families of Adaevski horses of specialized meat and dairy production direction, with a total livestock of 1197 heads, have been prepared for testing.

The growth, development and formation of meat content in Adai horses confirms a single pattern - the most intensive growth up to 6 months of age, and then its weakening and a high degree of dependence on paratypical factors. 


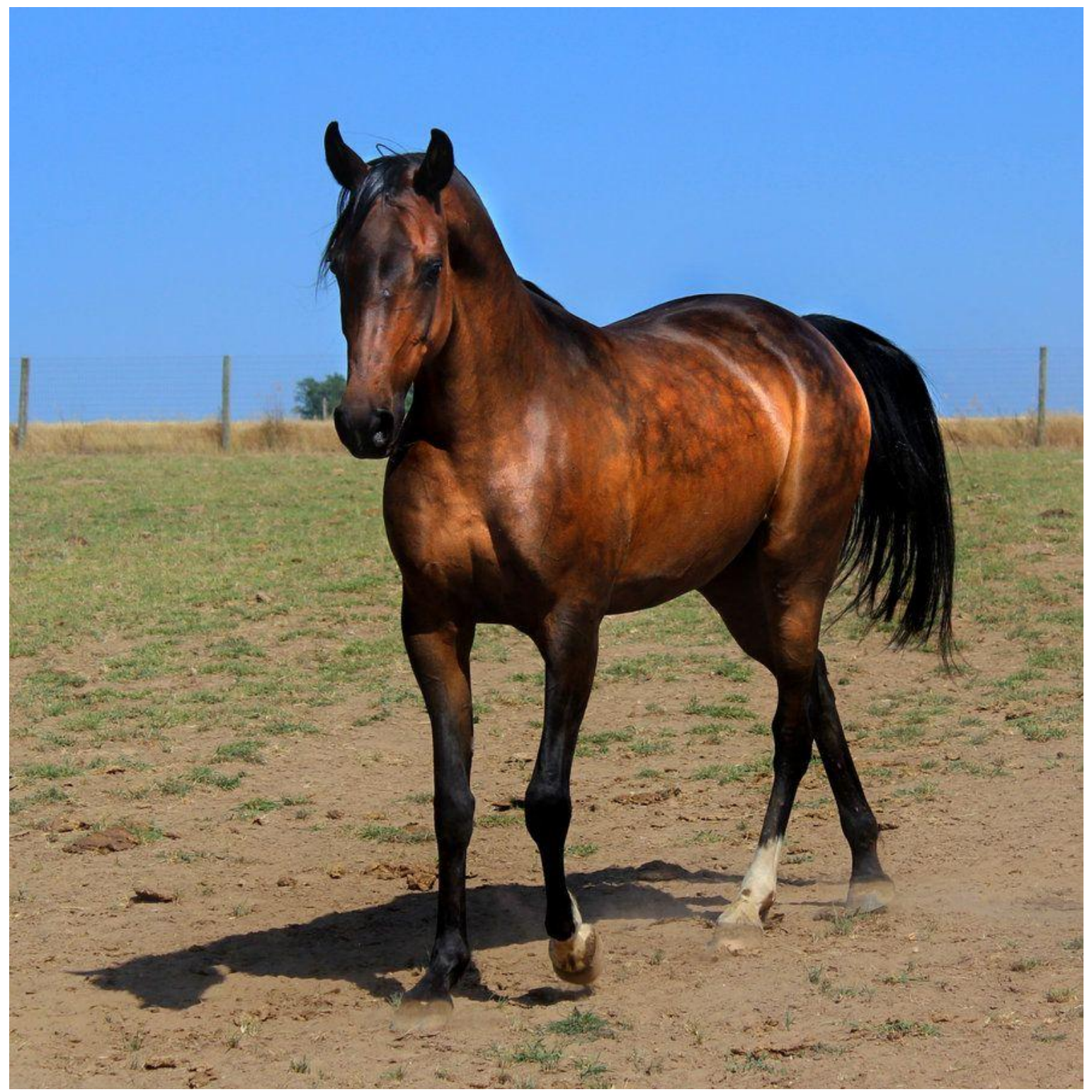

Uneven growth of tissues - bone, muscle and fat, which form the meat of the carcass of horses, changes not only their ratio, but also the physicochemical properties and biological (nutritional) value of meat. Knowledge of the patterns of growth and development allows us to recommend the optimal technology of pasture rotation and the organization of feeding animals, in particular, individuals with breeding value. 


\section{CONCLUSION}

The selection of highly productive individuals, successfully combining a pronounced maternal instinct of genotypes, will not only normalize the reproductive function of mares, but also ensure a high business yield of young animals, because in the future grazing livestock will remain the most important way to use arid zones for a long time.

Due to anthropogenic influence, the number of desert and saline areas with extremely rare and saline vegetation is rapidly growing in the world, where only rare ecotypes of local horses, such as the Adayev horse (perhaps even in the singular), can survive, and therefore the importance of this species for the country increases significantly. Consequently, our attitude to the breeding of the Adaevskaya horse with its prospects for pedigree sales for export should be viewed as a constantly growing gold and foreign exchange reserve.

\section{REFERENCE LIST}

Chauvin R. (1972) Animal behavior. M. Mir. 481 p. (in Russ).

Ernst L. K. (1981) To the farms of the second generation. Knowledge is power. №. 9. Pp. 1-2. (in Russ). Russ).

Hinde R. (1975) Animal behavior. Synthesis of ethology and comparative psychology. M. Mir. 855 p. (in

Imangaliev A. (1969) Adaev's horse. Alma-Ata. Kainar. 111 p. (in Russ).

Ivanova O.A. (1969) Genetic bases of breeding along lines. Genetic bases of breeding along lines. M. Nauka. Pp. 162-207. (in Russ).

Kalashnikov V.V. (2003) About research work in horse breeding. Problems of preserving the gene pool, improving the breeding and productive qualities of factory and local horse breeds. VNIIK. Pp. 5-9. (in Russ).

Kurochkina L.Y. (1966) Vegetation of sandy deserts of Kazakhstan. Vegetation cover of Kazakhstan. The science. Pp. 89-102. (in Russ).

Kuzmin N.I. (1937) Level of feeding of mestizo foals (in stud farms). Horse breeding. №. 3. Pp. 10-13. (in Russ).

Laskov A. A. (1982) Training and testing of racehorses. 222 p. (in Russ).

Maligonov A. A. (1925) On the rate of growth of an animal organism, in various periods in connection with the size of the growing mass. Studies on the biology of agricultural animals: Tr. Kuban agricultural Institute. Vol. 3. Pp. 90-98. (in Russ).

Milyagin Y.A. (1957) The determining effect of environmental factors on the embryogenesis of unconditioned reactions. Ecology and embryogenesis. M., USSR Academy of Sciences. Pp. 39-43. (in Russ).

Nurushev M.Z. (2003) Behavior and productivity of the ADAI horse in the conditions of the Aral-Caspian region. Using the achievements of agricultural science in the stabilization of agricultural farms. Collection of proceedings. Aktubinsk. Pp. 295-298. (in Russ).

Sakharov S.I. (1967) Landscapes of the Eastern part of the mountain Mangyshlak. Development of geographical Sciences in Kazakhstan. Alma-Ata. Pp. 67-85. (in Russ). Russ).

Zotov A.A. (1967) Grassland farming of the German Democratic Republic. M. VNIITEISKH. 24 p. (in 


\title{
ИСПОЛЬЗОВАНИЕ АДАЕВСКОЙ ЛОШАДИ В СЕЛЬСКОМ ХОЗЯЙСТВЕ КАЗАХСТАНА
}

\author{
Виталий Дорохин ${ }^{1}$ \\ 1'Воронежский государственный технический университет, Воронеж, Россия, \\ E-mail: s1te@bk.ru
}

\begin{abstract}
Аннотация
В статье исследуется Адаевская лошадь (сейчас более 34 тысяч голов), выведенная в Казахстане на обширной территории Аралокаспийской пустыни. Она получила широкое распространение в нынешних административных границах Мангистауской и Атырауской областей, занимая более 30 миллионов гектаров пастбищ.

Адаевская лошадь происходит от адаевского племени казахов, кочевавших по Арало-Каспийской низменности. В суровых условиях полуострова Мангистау и пустынного плато Устюрт её невозможно заменить никаким другим животным. В связи с этим проблема развития продуктивного коневодства в регионе, его рационального использования имела не только значительную экономическую, но и социальную значимость, поскольку более 90\% продуктов питания завозилось извне. Кроме того, остро ощущалась нехватка кумыса и конины.

Типологические исследования в Казахстане проводятся давно. Как правило, объектом исследования была казахская лошадь с ее многочисленными видами и потомством. В начале прошлого века перед заводчиками стояли совершенно разные задачи - производство рабочей и армейской лошади. Здесь основное внимание уделялось скрещиванию хорошо приспособленных к стадному содержанию местных кобыл с жеребцами заводских пород - чистокровных, донских, тяжеловозных, а также арабских и ахалтекинских.
\end{abstract}

Ключевые слова: лошадь, земля, человек, природа, еда. 